膵リンパ管腫の 1 例

\begin{tabular}{llllllll}
\multicolumn{10}{c}{ 八千代病院外科 } \\
佐々木 英 二 & 秋 田 幸 彦 & 北 & 喜 \\
橋 本 瑞 生 & 佐 藤 太郎 & 七 野 滋 彦
\end{tabular}

今回，わ扎れは，脺原発のリンパ管腫の 1 切除例を経験したので，若干の文献的考 察を加えて報告する。

症例は51歳男性. 主訴なく, 1994年 5 月に会社の健康診断で肝機能異常を指摘された。 US, CT, MRI などにより，肝下面から上前腸骨棘の高さに至るまでの巨大な赛胞性腫 瘤を認めた。後腹膜原発の偽粘液腫あるいはリンパ管腫と術前診断し, 同年 7 月29日開 腹術を施行した，乳白色で軟らかい腫汮が肝下面から右側腹部にかけて存在し，膵・十 二指腸に強固に瘾着していたため, 手術は膵頭十二指腸切除術を施行した. 腫瘍は大き

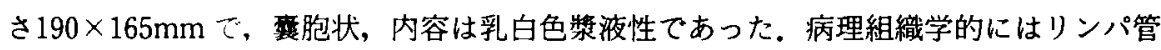
腫で，原発部位は膵と考えられた。

索引用語：膵臓腫瘍, リンパ管腫, 膵頭十二指腸切除術

\section{緒言}

脺原発のリンパ管腫は稀である.今回, われわれは, 膵原発のリンパ管腫の 1 切除例を経験したので, 若干 の文献的考察を加えて報告する。

$$
\text { 症例 }
$$

患者：51歳, 男性.

主訴：特記すべき事なし。

既往歴：急性虫垂炎 (35年前).

家族歴：特記すべき事なし。

現病歴：平成 6 年 5 月 20 日に, 会社の健康診断にて 肝機能異常, 高血圧を指摘され, 同年 6 月25日に当院 を受診，精查目的で入院となった。

入院時現症：体格，栄養状態ともに中等度. 貧血， 黄㾝なく，胸部身体的所見に異常を認めなかった。腹 部は平坦軟であったが, 右季肋部に弾性軟, 境界明瞭 な手拳大の腫瘤を触れた。

入院時検查所見：末梢血液所見には異常を認めな かった. 生化学所見では $\gamma$-GTPが軽度上昇していた。 腫瘍マーカーは正常範囲内であった（Table 1).

腹部超音波検查: 肝下面, 胆露, 膵頭部, 右腎臓で 囲まれる広い範囲に大小不同の多房性の襄胞を認めた

(Fig. 1).
Table 1 laboratory data on admission

\begin{tabular}{|c|c|c|c|}
\hline \multicolumn{2}{|c|}{ Blood examination } & T. Chol & $142 \mathrm{mg} / \mathrm{dl}$ \\
\hline $\mathrm{RBC}$ & $65 \times 10^{4} / \mathrm{mm}^{3}$ & AMY & $48 \mathrm{U} / \mathrm{dl}$ \\
\hline $\mathrm{Hb}$ & $15.6 \mathrm{~g} / \mathrm{dl}$ & $\mathrm{Na}$ & $143 \mathrm{mEq} / \mathrm{l}$ \\
\hline $\mathrm{Ht}$ & $45.5 \%$ & $\mathrm{~K}$ & $4.2 \mathrm{mEq} / \mathrm{l}$ \\
\hline WBC & $6.100 / \mathrm{mm}^{3}$ & $\underline{\mathrm{Cl}}$ & $120 \mathrm{mEq} / \mathrm{l}$ \\
\hline PLT & $43 \times 10^{3} / \mathrm{mm}^{3}$ & $\mathrm{Ca}$ & $10.0 \mathrm{mg} / \mathrm{dl}$ \\
\hline \multicolumn{2}{|c|}{ Coagulation test } & $P$ & $3.1 \mathrm{mg} / \mathrm{dl}$ \\
\hline Bless. T & $2.5 \mathrm{~min}$ & BUN & $14.4 \mathrm{mg} / \mathrm{dl}$ \\
\hline Coag. $\mathrm{T}$ & $10.5 \mathrm{~min}$ & Creatinine 0 & $0.73 \mathrm{mg} / \mathrm{dl}$ \\
\hline PT & $103 \%$ & FBS & $82 \mathrm{mg} / \mathrm{dl}$ \\
\hline PTT & $33 \mathrm{sec}$ & CRP & $0 \mathrm{mg} / \mathrm{dl}$ \\
\hline Fibrinogen & $\mathrm{n} \quad 434 \mathrm{mg} / \mathrm{dl}$ & Urinalysis & \\
\hline \multicolumn{2}{|c|}{ Blood chemistry } & protein & - \\
\hline T.P. & $6.5 \mathrm{~g} / \mathrm{dl}$ & sugar & \pm \\
\hline Alb. & $4.29 \mathrm{~g} / \mathrm{dl}$ & occult blood & - \\
\hline GOT & $24 \mathrm{IU} / l$ & bilirubin & - \\
\hline GOT & $27 \mathrm{IU} / l$ & \multicolumn{2}{|l|}{ Tumor marker } \\
\hline$\underline{\mathrm{LDH}}$ & $190 \mathrm{IU} / l$ & CEA & $2.5 \mathrm{ng} / \mathrm{ml}$ \\
\hline ALP & $168 \mathrm{IU} / l$ & CA19-9 & $9 \mathrm{U} / \mathrm{ml}$ \\
\hline$\gamma$ GTP & $94 \mathrm{IU} / l$ & AFP & $5.2 \mathrm{ng} / \mathrm{ml}$ \\
\hline LAP & $56 \mathrm{IU} / l$ & Erastasel & $170 \mathrm{ng} / \mathrm{dl}$ \\
\hline ChE & $0.93 \Delta \mathrm{pH}$ & & \\
\hline
\end{tabular}

腹部造影 Computed Tomography（以下, CT と略 す)：右腹部全体を占拠する $12 \times 7 \mathrm{~cm}$ の境界明睹で内 部均一な Low density mass を認めた。この病変は膵 


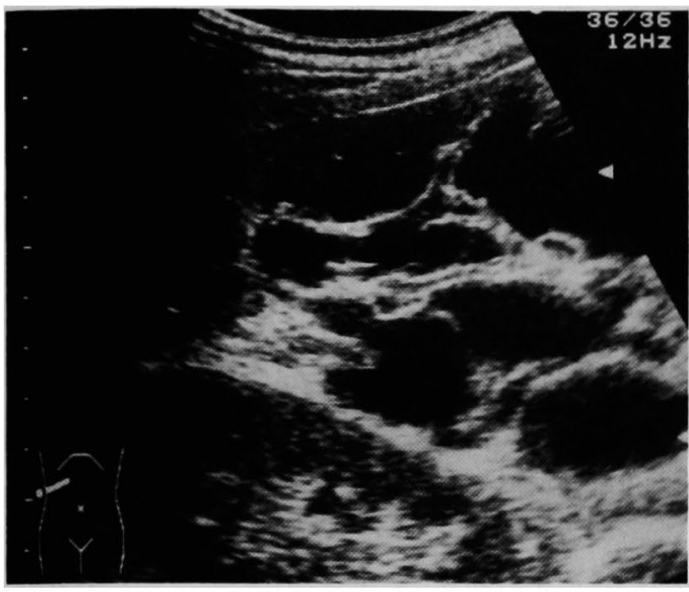

Fig. 1 Abdominal ultrasonography shows a large polycystic lesion in front of the right kidney.

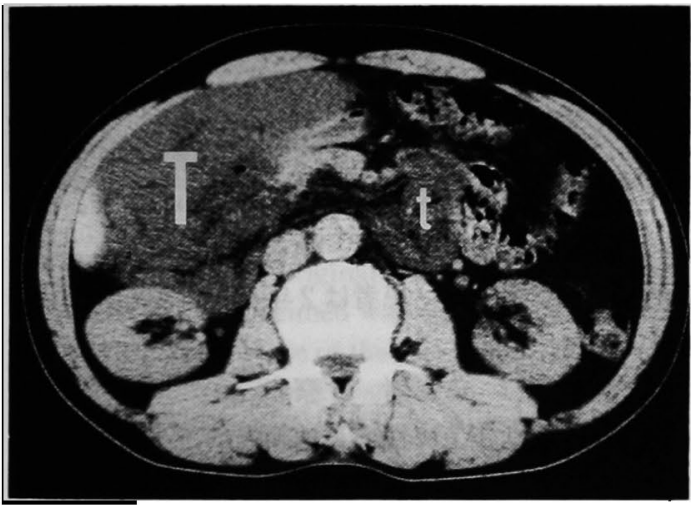

Fig. 2 Contrast-enhanced CT scan shows a large low density mass which is pointed as " $\mathrm{T}$ " occupies rightside of the abdominal cavity and partially beyond the midline (pointed as " $t$ ").

の後面, 大動脈の前面を通り左腎臓近くにまで張り出 していた (Fig. 2).

Magnetic Resonance Image (以下, MRI と略 す)：病変はMRI-T1強調前額断像（Fig. 3A）で低信 号, MRI-T2強調横断像 (Fig. 3B) で高信号を示し, 前額断像では尾側への広がりは腸骨棘におよんでい た。

上部消化管造影検査：十二指腸下行脚から，水平部 にかけて拡張不良を認め，十二指腸下行脚の右方への 偏位を認めた（Fig.4）。

腹部血管造影検査：前上膵十二指腸動脈，後上膵十 二指腸動脈がともに，右方へ圧排伸展されていた。血
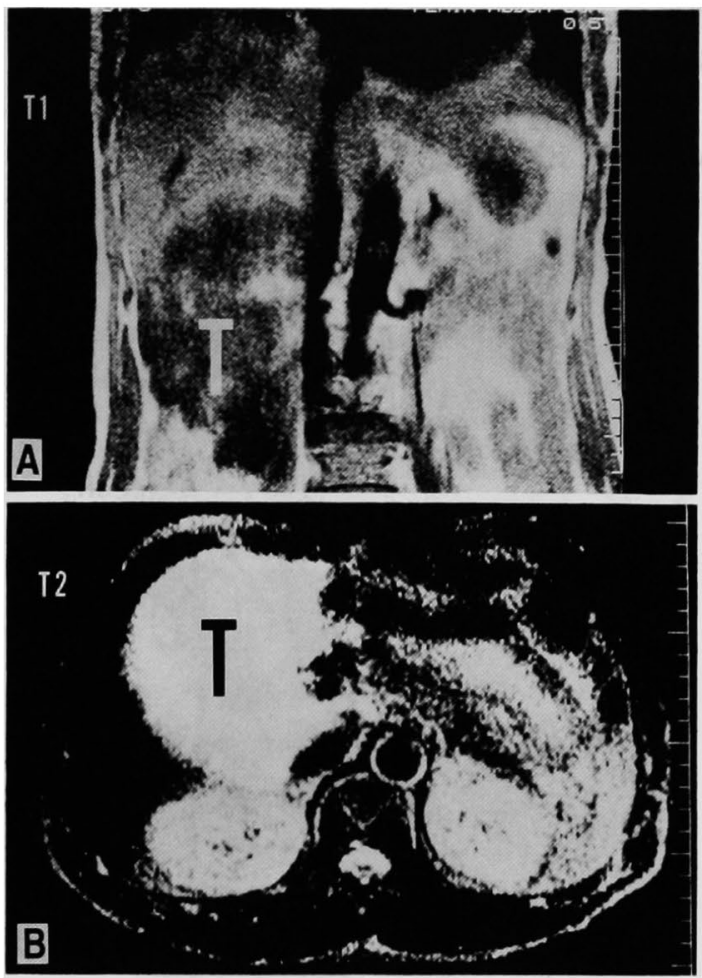

Fig. 3(A) $T_{1}$-weighted $M R$ image (frontal plain), showing a low large signal mass (pointed as " $\mathrm{T}$ ") spreading to lower right abdomen. (B) $T_{2}$. weighted MR image (horizontal plain), showing a high signal mass (pointed as "T").

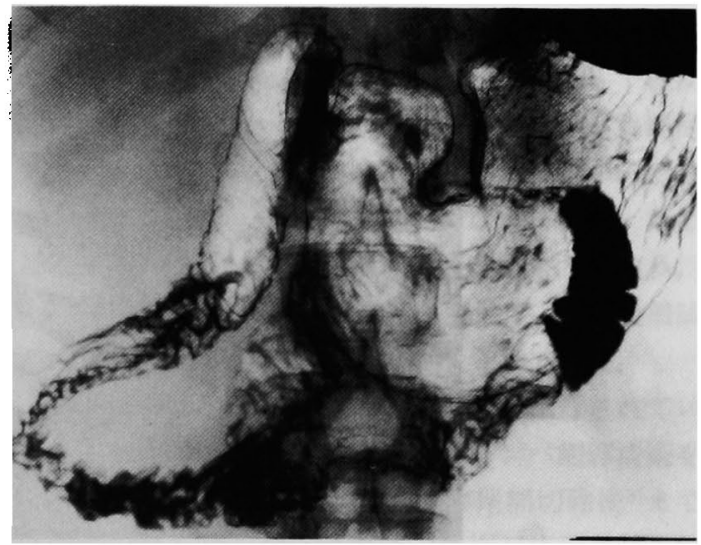

Fig. 4 Barium meal study shows imperfect distention of the duodenum from the second potion to the third potion and deviation of the duodenum to the rightside. 
管壁の広狭不整や腫韵濃染像は認めなかった（Fig. 5).

Endoscopic retrograde cholangiopancreatography (以下, ERCP と略す)：下部胆管は左側に偏位し, 主膵管は膀頭部で尾側に偏位していた。しかし，狭窄

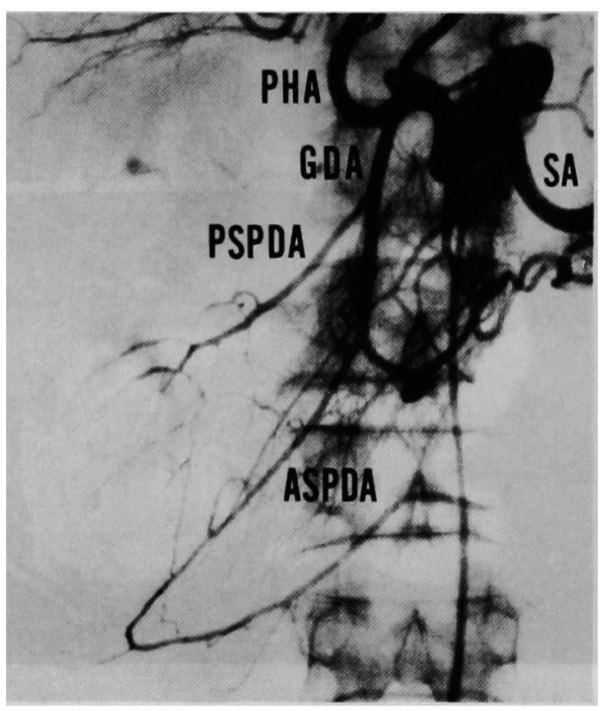

Fig. 5 Abdominal angiography shows deviation of the anterior and posterior superior pancreatoduodenal artery abbriveated to ASPDA and PSPDA. But there is no encasement, stenosis, nor tumor stain. SA: Splenic artery, PHA: Proper hepatic artery, GDA: Gastroduodenal artery.
や不整は認めなかった。

以上の所見より, 後腹膜原発のリンパ管腫, または 偽粘液腫と疑診し, 平成 6 年 7 月 29 日, 手術を施行し た.

術中所見 (Fig. 6)：腫慯の色調は孚白色で, 弾性软 であった，腫瘍は右腎および後腹膜からの剝離は容易 であったが, 脺頭部, 十二指腸, 胃幽門側との剝離は 困難であったので，幽門側胃切除術を含む膵頭十二指 腸切除術を施行した。膵は門脈左縁の位置で切除した が, 実質は柔らかだった。Treiz 靶带を切離し, 左腹部 へ突出した腫瘍部分とともに空腸も切断した.

切除標本：腫瘍は, 大きさ $19 \times 17 \times 5 \mathrm{~cm} て ゙$, 多房童 胞性の構造をしており, 実質部分に之しく, 㱏胞内に は乳白色の獎液を含んでいた（Fig.7）。

病理組織所見 (Fig. 8)：腫瘍は多房性の胞を持 ち,㖶胞内壁は一層の扁平な内皮細胞に覆われていた。 腫瘍組織は脂肪組織とともに, 膵小葉間に入り込んで いるが，小葉構造への破壊浸潤は認められなかった。 病理組織学的診断は亯胞性リンパ管腫であった。 以上 の病理組織所見と, 血管造影検査にて膵十二指腸動脈 のアーケードが右方へ偏位压排されていたこと, 術中 所見では腫瘍は強く膵頭部と癒着していたことより, 原発は膵と診断した。患者は 2 年たつた現在，再発の 徵候はない。

考 察

リンパ管腫は非上皮性の良性腫瘍で，小児の頸部に 好発する。そのほか腋窝や後腹膜原発のものがよく知 られているが, 膵原発は稀で, 1913年に Koch が第 1 例
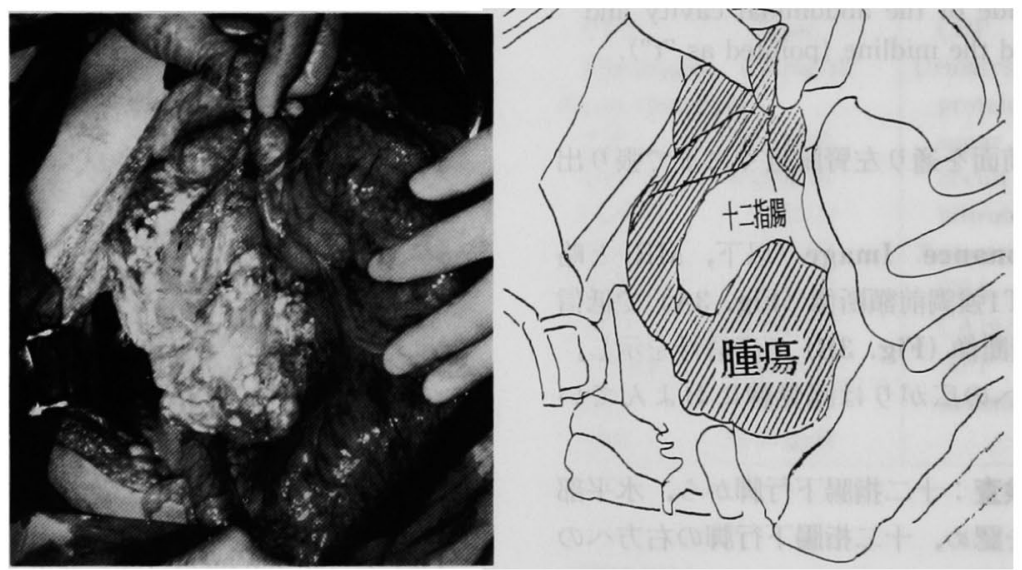

Fig. 6 Operative findings: Elastic soft milkwhite tumor adhered firmly to pylorus, duodenum, and the head of the pancreas. So, Pancreatoduodenectomy was performed. 

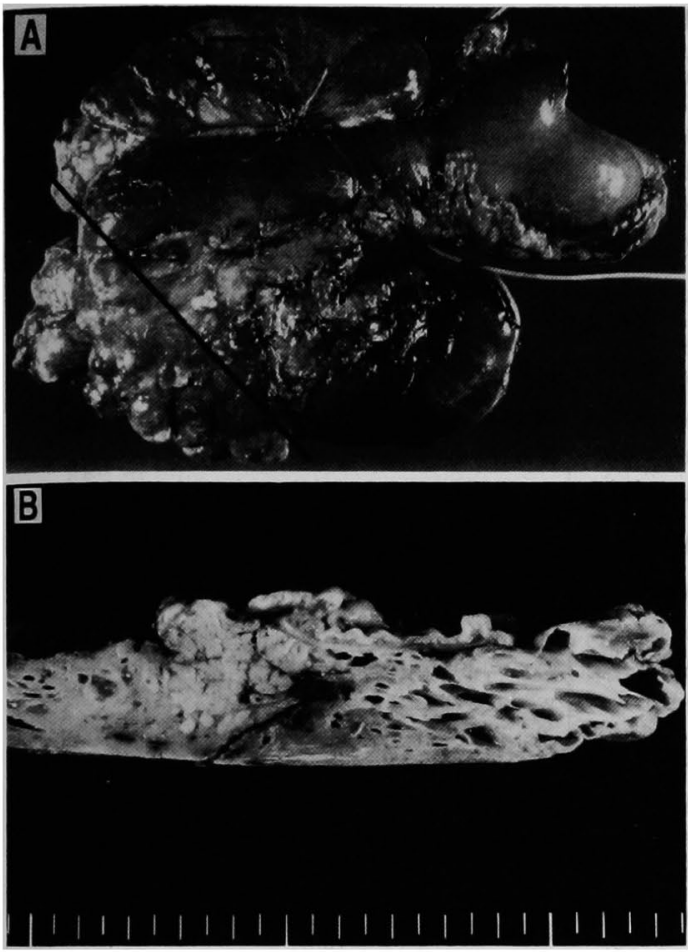

Fig. 7 (A) Surgical specimen: The tumor, $19 \times$ $17 \times 5 \mathrm{~cm}$ in size, originated from head of the pancreas. The specimen was cut along the black line. (B) Cut surface of the specimen : The tumor has honeycomb-like construction, full of milkwhite serum.

目”を報告しており，本邦では高雄"が1965年に報告し てから，自験例を含めて18例の報告がある(Table 2).

リンパ管腫は組織形態学的に，単純性 (capillary), 海綿状 (cavernous)，票状 (cystic) の3 型に分類され $ろ^{6 !}$.これは単房性か，多房性か，あるいは，壁や実質 に対する管腔や㐮胞の割合によって決まると思われ， あくまで肉眼的な分類で, 相互に移行性があり, 同一 標本においてもこれら 3 型が混在している場合もあ り，はっきりと分類できないこともある，本邦18例中 では顀状が13例を占めており，四肢によくみられる単 純性は 1 例もない. 口唇, 煩部, 舌などの周囲が筇組 織に囲まれた部位ではリンパ管構造が小さくて，単純 性, 海綿状となり, 頸部, 腋窝, 縦隔, 胸壁などの疎 な脂肪組織がある部位ではリンパ管は容易に堌大し壤 状リンパ管腫の形態をとるといわれている.

診断には, CT, US, Angiogram, ERCP な゙が各 症例に適宜行われている。膵原発あるいは後腹膜原発

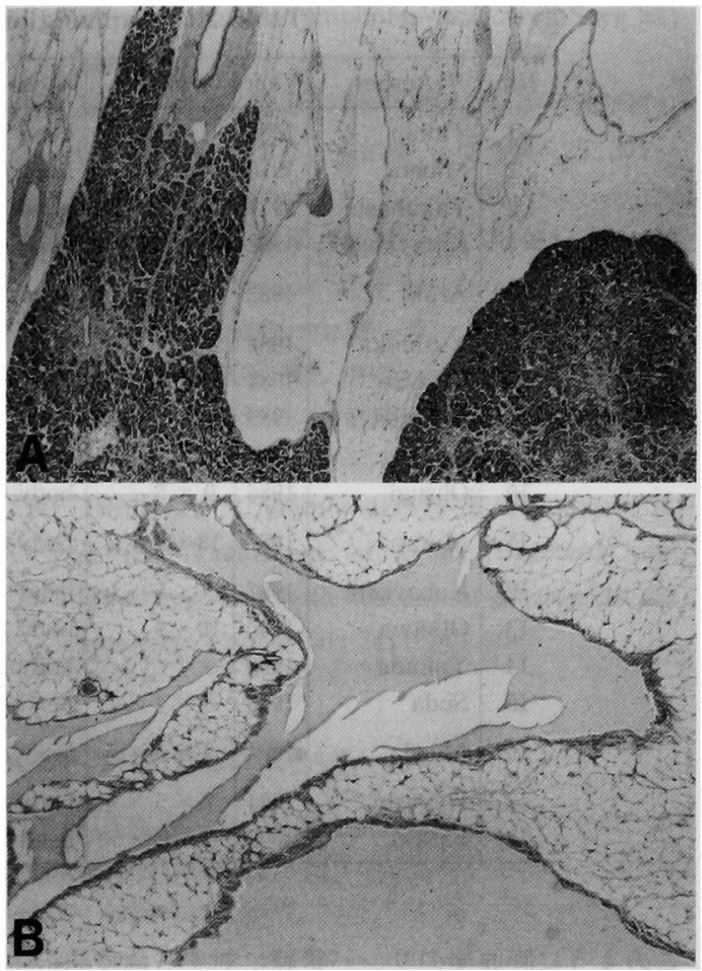

Fig. 8 The microscopic specimen showing small and large lumina of the lymphatic duct, which are separated by thin or thick connective tissue. Lumina are surrounded by a layer of flat cells (H-E stain, (A) : $\times 5,(B): \times 10)$.

のリンパ管腫を疑った場合，確定診断にはUS下経皮 的穿刺による乳潷の証明と, リンパ管造影を要すると いわれている7が，ほとんどがリンパ管腫を疑ってお らず，本邦では18例中 1 例に Murao ら ${ }^{8 /}$ US 下経皮 的穿刺を施行したのみで，リンパ管造影を行った症例 はない.われわれもリンパ管腫を一応疑ったものの， 穿刺や造影検査をするには至っていない，また，たと え穿刺したとしても，壤胞内容は血性のこともあり， 実際，Muraoらの症例でも内容は血性であり，術前は 出血を伴った多房性の膵哄胞と診断されていた。

記述のあった13例全例に手術的治療が施行されてい る、術式は単なる亯胞切除術から，リンパ節郭清術を 伴った膵頭十二指腸切除術や，膵体尾部切除術 ${ }^{8}$ まて 様々である。なかには囊胞空腸吻合術が施行された例 もある.予後は良好で，1 例2)が吻合不全により術死し ているのみである，再発例も本邦では 1 例もない（海 外では報告されている活)。 
Table 2 Lymphangioma of the pancreas in Japan.

\begin{tabular}{|c|c|c|c|c|c|c|}
\hline No. & Auther & Year & Size & Location & Pathology & operaion \\
\hline 1 & Takao & 1965 & $5 \times 10 \times 13$ & head & cavernous & pancreatoduodenectomy \\
\hline 2 & Mineta & 1970 & over fist & body tail & cavernous & distal partial pancreatectomy \\
\hline 3 & Takahashi & 1977 & & head & cystic & no description \\
\hline 4 & Katayanagi & 1982 & over fist & head & cystic & splenectomy and cystectomy \\
\hline 5 & Araki & 1983 & $19 \cdot 9 \cdot 9$ & head & cavernous & $\begin{array}{l}\text { pancreatoduodenectomy } \\
\text { with lymphnode dissection }\end{array}$ \\
\hline 6 & Yoshioka & 1983 & & body tail & cystic & distal partial pancreatectomy \\
\hline 7 & Ohshiro & 1984 & $10 \times 10 \div 9$ & & cystic & no description \\
\hline 8 & Hashiba & 1985 & $7 \times 6 \times 4$ & body & cystic & no description \\
\hline 9 & Tanaka & 1986 & $18: 9 \cdot 8$ & body tail & cavernous & distal partial pancreatectomy \\
\hline 10 & Ohsugi & 1986 & $9 \times 5$ & body tail & cavernous & no description \\
\hline 11 & Murao & 1987 & $13 \times 9 \times 5$ & body tail & cystic & $\begin{array}{l}\text { distal partial pancreatectomy } \\
\text { splenectomy }\end{array}$ \\
\hline 12 & Kobayashi & 1987 & $5 \times 5$ & head & cystic & no description \\
\hline 13 & Oikawa & 1990 & $10 \times 9$ & body tail & cystic & cystectomy \\
\hline 14 & Takada & 1990 & & body tail & cystic & cystjejunal anastomosis \\
\hline 15 & Suda & 1993 & $8 \times 4 \times 2$ & head & cystic & wedge resection of pancreas \\
\hline 16 & Maeda & 1994 & $9 \times 5 \times 5$ & beay body & cystic & $\begin{array}{l}\text { distal partial pancreatectomy } \\
\text { with lymphnode dissection }\end{array}$ \\
\hline 17 & Hayashi & 1994 & $7 \times 5 \times 4$ & body tail & cystic & wedge resection of pancreas \\
\hline 18 & Sasaki & 1996 & $19 \times 17 \times 5$ & head & cystic & pancreatoduodenectomy \\
\hline
\end{tabular}

このように膵原発のリンパ管腫に対する治療法の主 流は外科的治療法であるか，これはそのほとんどが術 前に膵襄胞性病変と診断されていることによると思わ 机る。

一方，小児科小児外科領域における頸部，葆窝，舌， 㚘部，四肢などに発生するリンパ管腫の治療の第一選 択は, 免疫賦活倣 (Biological response modifiers： BRM) の一種である“OK-432”（商品名：ピシバニー ル）局注療法となっており，極めて良好な成績をあげ ている ${ }^{11121}$. 手技は簡单で, 低侵襲であるし, 治㦄部位 になんら障害も残さず，美容的にも極めて優れた結果

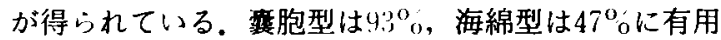
で，リンパ管腫全体でも約 $70 \%$ 症例に有用であるの で, 䪄胞型が多い脺原発のリンパ管腫にもかなりの成 績が期待できると思われる．特に膵との痹着が強く手 術をするならば脺頭十二指腸切除術や膵体尾部切除術 とならざるを得ない症例や，何らかの合併症のために 全身状態不良な症例に術前に診断がつけば，是非試み たい治療法である。

また，OK-432局注療法が無効であったときには，外 科的治療の前にブレオマイシン局注療法を第 2 選択の 治療法としてみるのもよいかもしれない( ${ }^{13)}$. Tanig.

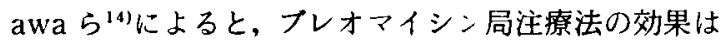
著効 $39 \%$ ，有効 $42 \%$ ，無効 $18 \%$ となっている.
ただこれらの治療法を選択するには、リンパ管腫 と診断することが前提となってくるのて，膵や後腹膜 原発の雍胞性病変をみた場合リンパ管腫も鑑別すべき 疾患として念頭に置き，積極的にUS下䧶胞穿刺やリ ンパ管造影を施行すべきと思われる。

\section{結語}

膵リンパ管腫の 1 例に対し，膵頭十二指腸切除術を 施行し有効であったためこれを報告した。

本邦では文献的には18例目と思わ扎た。

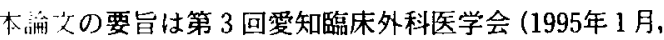
名古屋）にて発表した

\section{文献}

1) Koch $\mathrm{K}$ : Beitaflge zur Patholgie der Bauchspeicheldruflse. Virchows Arch [A] 214 180-206, 1913

2）高雄哲朗, 服部龍夫, 斉藤喜八他：膆頭部に発生女 る海綿状リンパ管腫. 癌の臨 $11: 38$ 42, 1965

3) Koshy A, Tandor RK, Kapur BM, et al: Retroperitoneal lymphangioma. Am J Gastroenterol 69: $485-490,1978$

4) Sabin FR: The lymphatic system in human embryos with a consideration of the morphology of the system as a whole. Am J Anat $9: 43$. 1909 
5) Stewert WF, Treves N : Lymphedema. Cancer 1: $64-82,1948$

6) Wagner $G$ : Lymphangioma. Arch Clin Chir $20: 6+1-707,1877$

7) Radin $R$, Weiner $S$, Koenigsberg $M$, et al: Retroperitoneal cystic lymphangioma. AJR $140: 733,1983$

8) Murao T, Toda K, Tomiyama Y : Lymphangioma of the pancreas. A case report with electron microscopic observation. Acta Pathol Jpn $37: 503-510,1987$

9) Raszkowski HJ, Rehbock DJ, Cooper FG: Mesenteric and retroperitoneal lymphangioma. Am J Surg 97 : 363, 1965

10) Henzel JH, Pories WJ, Burget DE, et al :
Intra-abdominal lymphangioma. Arch Surg 93 : 304,1966

11）荻田修平, 伝 俊秋, 中村 香他：リンパ管理腫の OK-432局注療法による治療。小児外科 $25: 371 一$ 376, 1993

12) Ogita S, Tsuto T, Deguchi E, et al: OK-432 therapy for unresectable lymphangioma in children. J Pediatr Surg 26:263-270, 1991

13）由良二郎, 橋本 俊, 水野 孝他：小児の頝部腫 瘤, 特に隻胞状リンパ管腫と Bleomycin の効果に ついて。少外科・内科 $8: 279-285,1976$

14) Tanigawa $N$, Shimomatsuya $T, T$ akahashi $K$, et al: Treatment of cystic hygroma and lymphangioma with the use of Bleomycin fat emalsion. Cancer $60: 741-749,1987$

\title{
A CASE OF LYMPHANGIOMA OF THE PANCREAS
}

\author{
Eiji SASAKI, Yukihiko AKITA, Yoshimi KITAGAWA, Mizuo HASHIMOTO, \\ Taichirou SATO and Shigehiko SHICHINO \\ Department of Surgery, Yachiyo Hospital
}

A case of lymphangioma of the pancreas in a 51-year-old man is presented. In May 1994, the patient was admitted to the hospital because of impaired function that was pointd out at a medical checkup. A large cystic tumor was found in the right hypochondrial region with ultrasonography, computed tomography, and magnetic resonance imaging. Psuedomyxoma or lymphangioma arising in the retroperitoneal cavity was most probable preoperatively. Pancreatoduodenectomy was perofrmed because the tumor made firm adhesion to the duodenum and head of the pancreas on July 29, 1994. The surgical specimen mearuring $190 \times 165 \mathrm{~mm}$ had a sponge-like structure with milky serosal fluid in it and was diagnosed histologically as cavernous lymphangioma arising in the pancreas. 